\title{
Antinociceptive and anti-inflammatory properties of methanol fruit extract of Quercus incana in rat and mice models
}

\author{
Muhammad Saeed $^{1 *}$, Farah Gul ${ }^{1,2}$, Zakiullah', Syed Naeemuddin Gilani ${ }^{2}$, \\ Yaqoob Ur Rehman ${ }^{2}$, Inamullah Khan ${ }^{1}$, Naveed Muhammad ${ }^{3}$ and Haroon Khan ${ }^{3}$ \\ ${ }^{1}$ Department of Pharmacy, University of Peshawar, ${ }^{2}$ P. C. S. I. R. Laboratories Complex, Jamrud Road, Peshawar, \\ ${ }^{3}$ Department of Pharmacy, Abdul Wali Khan University, Mardan 23200, Pakistan \\ *For correspondence: Email: saeedrph@upesh.edu.pk, saeedrph2000@yahoo.com
}

\begin{abstract}
Purpose: To investigate the anti-inflammatory and antinociceptive properties of crude methanol fruit extract of Quercus incana (QI), as well as its acute toxicity and phytochemical profile.

Methods: Two animal models were used: Wistar rats for carrageenan-induced paw inflammation and Swiss albino mice for acetic acid-induced writhing test (hot plate method for anti-nociceptive effect). The extract was also subjected to phytochemical screening using standard procedures.

Results: The extract showed significant $(p<0.01)$ anti-inflammatory effect at doses of 50,100 and 150 $\mathrm{mg} / \mathrm{kg}$. It also evoked significant anti-nociceptive activity (both peripheral and central analgesia) at all test doses (25, 50 and $100 \mathrm{mg} / \mathrm{kg} ; p<0.01)$. Acute toxicity data revealed that the extract was non-toxic up to a dose of $425 \mathrm{mg} / \mathrm{kg}$, while phytochemical screening indicated the presence of alkaloids, flavonoids, steroids, terpenoids, anthraquinones, tannins, coumarins, reducing sugars and resins.

Conclusion: These results suggest that Quercus incana fruit contains compounds with antinociceptive and anti-inflammatory properties.
\end{abstract}

Keywords: Quercus incana fruit, Antinociceptive, Anti-inflammatory, Phytochemical profile

Tropical Journal of Pharmaceutical Research is indexed by Science Citation Index (SciSearch), Scopus, International Pharmaceutical Abstract, Chemical Abstracts, Embase, Index Copernicus, EBSCO, African Index Medicus, JournalSeek, Journal Citation Reports/Science Edition, Directory of Open Access Journals (DOAJ), African Journal Online, Bioline International, Open-J-Gate and Pharmacy Abstracts

\section{INTRODUCTION}

Natural therapeutic agents have been used for the treatment of various diseases since the beginning of human life [1]. Traditional healers use these products on the basis of their extensive personal experiences, mostly without scientific backgrounds. Researchers believe that approximately $15 \%$ of medicinal plants have been subjected to phytochemical analysis, and about $6 \%$ to biological screening [2]. The rest have remained unexplored. The study of phytochemical composition of medicinal plants is important for discovery of new and effective therapeutic agents.

Quercus incana (QI) is commonly known as blue jack oak or cinnamon oak [3]. Quercus is an important genus of temperate regions in Pakistan. It has been reported that different species of Quercus possess antibacterial, antioxidant and gastro-protective effects [4].The galls of Quercus are used in the treatment of wounds or burns associated with bacterial infections [5].

There are many ethno-medicinal uses of QI. The 
acorns are administered as diuretic and antigonorrheal agent, and also as astringent for treating indigestion and asthma. They are also used as fuel for making fire and charcoal [6]. Various phytochemical compounds such as phenolics, proanthocyanidins, flavan-4-ols, lupeol, $\beta$-sitosterol and ursolic acid and quercusides $A$ and $B$ have been reported in this genus [7].

In the present study we evaluated the effect of methanol extract of Quercus incana fruit on various pain and inflammation animal models in order to ascertain any scientific basis for the use of this fruit in treatment of painful inflammatory conditions.

\section{EXPERIMENTAL}

\section{Plant material}

Fresh fruits of Ql were collected from Gadoon Gani Chatra, District Swabi, Pakistan in June 2011, and were authenticated by Prof Dr Muhammad Ibrar, a taxonomist in the Department of Botany, University of Peshawar. A voucher specimen (Bot.20052 (PUP) was deposited in the Herbarium of the same department.

\section{Chemicals}

The chemicals used in this study and their sources are aspirin (Reckitt and Colman, Pakistan); acetic acid, Naloxone ${ }^{R}$ hydrochloride and sodium chloride (Sigma Chemicals Company, St. Louis, USA); carrageenan (Sigma Lambda, USA) and Tramadol $^{R}$ (Searle Pakistan Ltd). Sterile normal saline was used as control in all studies.

\section{Animals}

Swiss albino mice (18 - $25 \mathrm{~g}$ ) and Wistar rats $(190-260 \mathrm{~g})$ of both sexes were used. The animals were kept under standard laboratory conditions at $25^{\circ} \mathrm{C}$. They were fed laboratory diet ad libitum and allowed free access to drinking water under standard environmental conditions of temperature $\left(25^{\circ} \mathrm{C}\right)$ in a $12 \mathrm{~h}$ dark/12 h-light cycle. The animal study was approved by the Ethical Committee of the Department of Pharmacy, University of Peshawar (no. 444). All the experimental animals were treated according to ethical principles established in 1979 for laboratory animals in the services of mankind, Lyons, France [8]

\section{Preparation of plant extract}

The fruits $(6 \mathrm{~kg})$ were dried in a shade, chopped into small pieces and powdered. The powdered plant material was extracted by maceration with methanol at ambient temperature for 2 weeks. The methanol-soluble material was filtered through filter paper and the residue obtained was again macerated with methanol. This process was repeated three times and the combined filtrate was concentrated under vacuum at low temperature $\left(40^{\circ} \mathrm{C}\right)$ using a rotary evaporator [9], resulting in $984 \mathrm{~g}$ of a crude, dark brown semi-solid extract.

\section{Acute toxicity studies}

Swiss albino mice $(n=6)$ of either sex were used for the acute toxicity test. They were given different increasing or decreasing intra-peritoneal (i.p.) doses of the extract according to the response of animals [10]. The doses administered were 50, 100, 150, 200, 250, 300, 350,400 and $425 \mathrm{mg} / \mathrm{kg}$, while the control group received only normal saline. All the groups were observed for any gross effect or mortality within a period of $24 \mathrm{~h}$.

\section{Phytochemical screening}

The extract was subjected to phytochemical screening for the presence of alkaloids, flavonoids, saponins, tannins, anthraquinones, reducing sugars, coumarins and steroids/triterpenes, according to standard procedures [11].

\section{Acetic acid-induced writhing test}

The antinociceptive property the extract of was determined by acetic acid-induced abdominal constriction test in mice [12]. Albino mice of either sex weighing $18-22 \mathrm{~g}$ were used. All animals were fasted $2 \mathrm{~h}$ before the start of experiment and were randomly assigned to five groups (6 per group). Group I was injected with normal saline $(10 \mathrm{~mL} / \mathrm{kg})$; this served as control. Group II received the standard drug aspirin (100 $\mathrm{mg} / \mathrm{kg}$ ), while the remaining groups III, IV and V were injected with 25, 50, and $100 \mathrm{mg} / \mathrm{kg}$ i.p. of QI extract, respectively. After $30 \mathrm{~min}$ of saline, aspirin and plant extract injection, the animals were treated i.p. with $1 \%$ acetic acid $(10 \mathrm{~mL} / \mathrm{kg})$. The number of abdominal constrictions (writhes) was counted after $5 \mathrm{~min}$ of acetic acid injection for a period of $20 \mathrm{~min}$. Protection (\%) against nociception was computed using Eq 1.

Protection $(\%)=\{1-(\mathrm{T} / \mathrm{C})\} \times 100$ 
where $T$ and $C$ are the number of writhes in test and control animals, respectively.

\section{Hot plate test}

Albino mice of either sex $(n=6)$ weighing 18 $22 \mathrm{~g}$ were acclimatized to laboratory conditions $1 \mathrm{~h}$ before the start of experiment with feed and water ad libitum. The animals were then subjected to pre-testing on hot plate (Harvard apparatus) maintained at $55 \pm 0.1^{\circ} \mathrm{C}$. Animals having latency time greater than $15 \mathrm{~s}$ (latency time) on the hot plate during pre-testing were rejected [13]. Group I was treated with saline (10 $\mathrm{mL} / \mathrm{kg}$ ), and group II was treated with Tramadol (30 mg/kg i.p). Groups III, IV and V were treated with 25,50 , and $100 \mathrm{mg} / \mathrm{kg}$ QI i.p. respectively. After $30 \mathrm{~min}$, the animals were placed on hot plate and the latency time prior to licking or flicking of hind limb or jumping) was measured in seconds. To prevent tissue damage, a cut-off time of $30 \mathrm{~s}$ was set. Groups VI and VII were treated with Naloxone ${ }^{R}(0.5 \mathrm{mg} / \mathrm{kg}$ s.c.) and after 10 min these groups were treated with QI (100 and $150 \mathrm{mg} / \mathrm{kg}$, i.p), while group VIII was treated with Tramadol $^{R}$ (30 mg/kg i.p.) after $10 \mathrm{~min}$ of Naloxone ${ }^{R}$ injection. Analgesia was defined by increase in latency time (s) which was recorded for all groups at 0, 30, 60, 90 and $120 \mathrm{~min}$., and calculated using the equation below (Equation 2).

$\%$ Analgesia $=($ Test latency - control latency $) /($ Cut off time - control latency $) \times 100$

\section{Carrageenan-induced edema}

Carrageenan-induced hind paw edema test was conducted according to the method previously described by Winters et al [14]. The animals were randomly divided in five groups, each of six animals. Group I was treated with normal saline $(10 \mathrm{~mL} / \mathrm{kg})$, group II with Aspirin ${ }^{\mathrm{R}}(100 \mathrm{mg} / \mathrm{kg})$, while the other three groups were treated with QI at 50,100 , and $150 \mathrm{mg} / \mathrm{kg}$, (i.p.), respectively. Acute inflammation was produced by sub-plantar injection of $0.1 \mathrm{~mL}$ of $1 \%$ suspension of carrageenan, in the right hind paw of the rats, $1 \mathrm{~h}$ after oral administration of the test sample. Carrageenan was also administered via the same route to rats in the positive and negative controls. Paw volume was measured plethysmometrically (LE 7500 plan lab S.L) 0,1 , 2,3 and 4 hours after the carrageenan injection. Aspirin $^{R}(100 \mathrm{mg} / \mathrm{kg}$, i.p.) was used as positive control. Inflammation was quantified according to the method described by Planichamy et al (Eq 3) [15].

Inhibition $(\%)=\{A-(B / A)\} 100$ where $A$ and $B$ are increases in paw volume of control and drug-treated animals, respectively.

\section{Statistics}

Results are presented as mean \pm SEM $(n=6)$. SPSS version 20.0 was used for the analysis of the data. ANOVA, followed by post hoc Dunnett's test for multiple comparisons. Values of $p<0.05$ were considered statistically significant.

\section{RESULTS}

\section{Phytochemical profile}

Preliminary phytochemcial screening of the extract revealed presence of alkaloids, flavonoids, steroids, terpenoids, anthraquinones, tannins, coumarins, reducing sugars and resins (Table 1).

Table 1: Phytochemical profile of crude fruit extract of Quercus incana

\begin{tabular}{ll}
\hline Phytochemical type & Presence \\
\hline Flavonoids & +++ \\
Alkaloids & + \\
Steroids & ++ \\
Saponins & $\mathrm{ND}$ \\
Anthraquinones & ++ \\
Reducing sugars & ++ \\
Coumarins & ++ \\
Terpenoids & +++ \\
\hline ND = Not detected; + = Trace; $++=$ present; +++ & $=$ \\
prominent
\end{tabular}

\section{Acute toxicity}

The $L_{50}$ of the extract was $425 \mathrm{mg} / \mathrm{kg}$. The animals exhibited weakness and respiratory distress prior to death.

\section{Acetic acid induced writhing test}

The fruit extract at doses of 25, 50 and 100 $\mathrm{mg} / \mathrm{kg}$ significantly reduced the number of aceticacid-induced abdominal constrictions by 62.59 , 74.30 and $82.96 \%$, respectively $(p<0.05)$ (Table 2).

\section{Effect of extract on rats in hot plate test}

Results of the hot plat test revealed that the extract produced a strong pain-relieving effect (Table 3). The protection conferred by the extract against heat-induced pain was dose-dependent. 
Table 2: Antinociceptive property of methanol extract of Quercus incana fruit in acetic acid-induced writhing test

\begin{tabular}{lcccc}
\hline Treatment & Dose & No. of writhes (mean) & $\begin{array}{c}\text { Inhibition } \\
(\mathbf{\%})\end{array}$ & $\begin{array}{c}\boldsymbol{P} \text {-value (95\% } \\
\text { CI) }\end{array}$ \\
\hline Normal saline & $10 \mathrm{ml} / \mathrm{kg}$ & 65.16 & 0 & \\
Aspirin & $100 \mathrm{mg} / \mathrm{kg}$ & $10.16 \pm 1.23^{\text {* }}$ & $84 . .40$ & $<0.01$ \\
Fruit extract & $25 \mathrm{mg} / \mathrm{kg}$ & $24.5 \pm 1.30^{* *}$ & 62.59 & $<0.01$ \\
& $50 \mathrm{mg} / \mathrm{kg}$ & $16.83 \pm 1.26^{* *}$ & 74.30 & $<0.01$ \\
& $100 \mathrm{mg} / \mathrm{kg}$ & $11.16 \pm 2.7^{* *}$ & 82.96 & $<0.01$ \\
\hline
\end{tabular}

Table 3: Antinociceptive activity of methanol fruit extract of Quercus incana in hot plate test

\begin{tabular}{|c|c|c|c|c|c|c|}
\hline Group & $\begin{array}{c}\text { Treatment } \\
\text { (/kg, i.p.) }\end{array}$ & $0 \mathrm{~min}$ & $30 \mathrm{~min}$ & $60 \mathrm{~min}$ & $90 \mathrm{~min}$ & $120 \mathrm{~min}$ \\
\hline \multicolumn{7}{|c|}{ Without naloxone } \\
\hline $\begin{array}{l}\text { Normal } \\
\text { saline }\end{array}$ & $10 \mathrm{ml}$ & $8.20 \pm 0.03$ & $8.23 \pm 0.08$ & $8.17 \pm 0.09$ & $8.20 \pm 0.04$ & $8.13 \pm 0.11$ \\
\hline Extract & $25 \mathrm{mg}$ & $8.21 \pm 0.26$ & $10.90 \pm 0.40$ & $12.18 \pm 0.81^{*}$ & $11.76 \pm 0.41^{*}$ & $11.51 \pm 0.31^{*}$ \\
\hline Extract & $50 \mathrm{mg}$ & $8.25 \pm 0.60$ & $11 . .82 \pm 0.80$ & $13.45 \pm 0.50^{* *}$ & $13.28 \pm 0.81^{* *}$ & $13.06 \pm 0.88^{* *}$ \\
\hline Extract & $100 \mathrm{mg}$ & $8.29 \pm 0.70$ & $18.74 \pm 0.19^{*}$ & $22.70 \pm 0.10^{* *}$ & $22.11 \pm 0.11^{* *}$ & $21.91 \pm 0.62^{* *}$ \\
\hline Tramadol & $30 \mathrm{mg}$ & $8.20 \pm 0.03$ & $24.34 \pm 0.05^{\star *}$ & $24.86 \pm 0.06^{\star * *}$ & $24.75 \pm 0.08^{* * *}$ & $24.71 \pm 0.00^{* * *}$ \\
\hline \multicolumn{7}{|c|}{ With naloxone } \\
\hline Extract & $100 \mathrm{mg}$ & $8.21 \pm 0.35$ & $9.68 \pm 0.50^{* *}$ & $9.71 \pm 0.37^{* *}$ & $9.82 \pm 0.69^{* *}$ & $9.90 \pm 0.58^{* *}$ \\
\hline Extract & $50 \mathrm{mg}$ & $8.32 \pm 0.57$ & $9.70 \pm 0.68^{* *}$ & $9.65 \pm 0.80^{* *}$ & $9.72 \pm 0.52^{* *}$ & $9.76^{* *} \pm 0.81^{* *}$ \\
\hline Tramadol & $30 \mathrm{mg}$ & $8.25 \pm 0.09$ & $9.22 \pm 0.04^{* *}$ & $9.05 \pm 0.07^{* * *}$ & $9.25 \pm 0.08^{* * *}$ & $9.04^{* * *} \pm 0.00^{* * *}$ \\
\hline
\end{tabular}

Values are mean $\pm \operatorname{SEM}(\mathrm{n}=6) ;{ }^{*} p<0.05,{ }^{* *} p<0.01,{ }^{* * *} p<0.001$

\section{Effect of extract on carrageenan-induced paw edema}

The anti-inflammatory activity of the extract is presented in Table 4. Injection of carrageenan in the rat paws produced inflammatory edema which increased gradually. The QI extract at a dose of $150 \mathrm{mg} / \mathrm{kg}$ exhibited significant antiinflammatory activity $(p<0.01)$ which was maximum $3 \mathrm{~h}$ after carrageenan administration (60.27\% inhibition). The anti-inflammatory effect of Aspirin $(100 \mathrm{mg} / \mathrm{kg}$ ) was greater than that of the extract.

\section{DISCUSSION}

Results of preliminary phytochemical screening of methanol extract of QI fruit revealed presence of alkaloids, flavonoids, steroids, terpenoids, coumarins, reducing sugars, anthraquinones, and tannins. Flavonoids, steroids and tannins are known to have antinociceptive and antiinflammatory properties [16]. Thus the antinociceptive and anti-inflammatory effects produced by the extract may be attributed individually or collectively to its content of flavonoids and tannins.

Table 4: Anti-inflammatory activity of methanol fruit extract of Quercus incana in carrageenan-induced paw edema rat model

\begin{tabular}{|c|c|c|c|c|c|c|}
\hline \multirow[t]{2}{*}{ Sample } & \multirow{2}{*}{$\begin{array}{l}\text { Dose } \\
\text { (mg/kg } \\
\text { i.p.) }\end{array}$} & \multicolumn{5}{|c|}{ Paw volume (edema rate (\%) after injection) } \\
\hline & & $\mathrm{Oh}$ & $1 \mathrm{~h}$ & $2 h$ & $3 \mathrm{~h}$ & $4 h$ \\
\hline $\begin{array}{l}\text { Normal } \\
\text { saline }\end{array}$ & 10 & $0.67 \pm 0.027$ & $0.68 \pm 0.035$ & $0.68 \pm 0.025$ & $0.73 \pm 0.059$ & $0.73 \pm 0.038$ \\
\hline Extract & 50 & $0.64 \pm 0.019$ & $0.62 \pm 0.028(8.82)$ & $\begin{array}{l}0.59 \pm 0.068 \\
(13.23)\end{array}$ & $\begin{array}{l}0.58 \pm 0.071 \\
(20.54)\end{array}$ & $\begin{array}{l}0.59 \pm 0.017 \\
(19.17)\end{array}$ \\
\hline Extract & 100 & $0.56 \pm 0.051$ & $\begin{array}{l}0.50 \pm \\
0.071^{*}(26.47)\end{array}$ & $\begin{array}{l}0.41 \pm \\
0.030^{\star *}(39.70)\end{array}$ & $\begin{array}{l}0.40 \pm \\
0.038^{* *}(45.20)\end{array}$ & $\begin{array}{l}0.46 \pm \\
0.046^{\star}(36.98)\end{array}$ \\
\hline Extract & 150 & $0.47 \pm 0.060^{*}$ & $\begin{array}{l}0.35 \pm \\
0.034^{* *}(48.52)\end{array}$ & $\begin{array}{l}0.32 \pm \\
0.061^{* *}(52.94)\end{array}$ & $\begin{array}{l}0.29 \pm \\
0.068^{* *}(60.27)\end{array}$ & $\begin{array}{l}0.34 \pm \\
0.049^{\star *}(53.42)\end{array}$ \\
\hline Aspirin & 100 & $0.22 \pm 0.030^{* *}$ & $\begin{array}{l}0.19 \pm \\
0.032^{\star *}(72.05)\end{array}$ & $0.17 \pm 0.023^{* *}(75)$ & $\begin{array}{l}0.18 \pm \\
0.030^{* *}(75.34)\end{array}$ & $\begin{array}{l}0.18 \pm \\
0.033^{* *}(75.34)\end{array}$ \\
\hline
\end{tabular}

${ }^{*} P<0.05$ or ${ }^{* *} p<0.01$ was considered significant compared with control. Values in brackets represent \% decreases in paw volume relative to corresponding values for the normal saline group at each time interval 
Although the intraperitoneal $L D_{50}$ of the extract suggests that it is moderately toxic, it was found quite safe up to the therapeutic doses used in this study.

Acetic acid-induced abdominal constriction test is routinely used for evaluation of peripheral antinociceptive activity [17].The extract showed antinociceptive activity in acetic acid-induced writhing test in mice. This indicates that it possesses peripheral mediated antinociceptive activity. Since abdominal constriction response is thought to involve in part, local peritoneal receptors [18], it is likely that the extract interfered with these receptors to bring about analgesia. Pain sensation in acetic acid-induced writhing test is elicited through production of localized inflammatory responses due to cyclooxygenase (COX)-mediated release of free arachidonic acid from tissue phospholipids, and synthesis of PGE2 and PGF2, although the level of lipoxygenase products may also increase in peritoneal fluids [19]. These prostaglandin and lipoxygenase products cause inflammation and pain by increasing capillary permeability.

Antinociceptive effect, which results in inhibition of writhing, is exerted by inhibition of prostaglandin synthesis, a peripheral mechanism of pain inhibition. Indeed, acetic acid-induced writhing test has been associated with increase in the levels of PGE2 and PGF2 $\alpha$ in peritoneal fluid, as well as lipoxygenases, so the mechanism of antinociceptive activity of the extract may be linked to cyclooxygenases and/or lipoxygenases [20]. The significant inhibition of writhing reflux exhibited by the extract strongly indicates that QI has peripheral antinociceptive activity mediated through inhibition $\mathrm{COX}$ and local peritoneal receptors. Thus it may be suggested that the profound antinociceptive activity of the extract may be due to the interference of its active principles with release of pain mediators.

QI fruit extract at the tested doses 25,50 and $100 \mathrm{mg} / \mathrm{kg}$ significantly increased latency time for thermal stimulation. Like aspirin, it demonstrated late onset of antinociceptive effects which lasted beyond the 5th hour post-treatment. The hot plate test is used to distinguish between peripheral and central acting antinociceptive agents [20]. Our results are suggestive of central acting antinociceptive effects of the QI extract. QI showed a marked inhibition of heat-induced hyperalgesia by producing significant attenuation when compared with the control, although the antinociceptive effect of the standard drug Tramadol was stronger. The antinociceptive effect of QI was antagonized by Naloxone, a non-selective opioid receptor antagonist. This strongly indicates that the antinociceptive effect of this extract was due to activation/stimulation of opioid receptors. Further research is needed to find out the exact components responsible for this behavior.

The extract caused marked inhibition of carrageenan-induced edema in rats. Carrageenan-induced inflammatory process is believed to be biphasic. The initial phase seen in the $1 \mathrm{st} h$ is attributed to the release of histamine and serotonin. The second accelerating phase of swelling is due to the release of prostaglandins, bradykinin and lysozyme [21]. It has been reported that the second phase of edema is sensitive to both clinically useful steroidal and non-steroidal anti-inflammatory agents [22].

The anti-inflammatory activity exerted by the extract of QI suggests that it could affect kinin, prostaglandin, bradykinin and lysozyme synthesis. Inhibitory effect of the extract at the dose of $150 \mathrm{mg} / \mathrm{kg}$ on carrageenan-induced inflammation over period of $4 \mathrm{~h}$ is greater when compared to inhibition produced at a dose of 50 $\mathrm{mg} / \mathrm{kg}$ or at $100 \mathrm{mg} / \mathrm{kg}$. This shows a dosedependent inhibitory effect of the extract on inflammation. However, the anti-inflammatory effect of the extract was less potent than its antinociceptive activity.

\section{CONCLUSION}

This study demonstrates that the methanol fruit extract of QI possesses strong antinociceptive activity involving both peripheral and central mechanisms. The peripheral activity was augmented by opioid-independent central activity. The extract-induced suppression of inflammation at early and late phases may be due to its ability to inhibit release and/or activity of mediators involved in both phases of inflammation. This finding lends credence to its ethno-pharmacological uses. However, further studies are needed with respect to its exact mechanism(s) of action, the role of specific extract components as well as bioassay-directed isolation of the pharmacologically active phytochemical components of the plant.

\section{DECLARATIONS}

\section{Acknowledgement}

The authors acknowledge Pakistan Council of Scientific and Industrial Research, Peshawar, and HEJ Institute, Karachi for providing research laboratory facilities. 


\section{Conflict of Interest}

No conflict of interest associated with this work.

\section{Contribution of Authors}

The authors declare that this work was done by the authors named in this article and all liabilities pertaining to claims relating to the content of this article will be borne by them.

\section{REFERENCES}

1. Guimaraes R, Barros L, Carvalho AM, Ferreira ICFR. Infusions and decoctions of mixed herbs used in folk medicine: Synergism in antioxidant potential. Phytother Res 2011; 25: 1209-1214.

2. Dhami N. Trends in Pharmacognosy: A modern science of natural medicines. J Herbal Med 20133; 123-131.

3. Shah ST, Ahmad H, Zamir R. Pollen Morphology of three Species of Quercus (Family Fagaceae). J Agri Soc Sci 2005; 1813-2235.

4. Rao N, Mittal S, Sudhanshu, Menghani E In vitro phytochemical screening, antioxidant \& antimicrobial activity of the methanolic extract of Quercus infectoria $L$. Int J Pharm Sci, 2013; 5(2): 273-277.

5. Jamil M, Haq I, Mirza B, Qayyum M. Isolation of antibacterial compounds from Quercus dilatata $L$. through bioassay guided fractionation. Ann Clin Microbiol Antimicrobials 2012; 11:11.

6. Jan S, Khan MA, Sirajuddin, Murad W, Hussain M, Ghani A. Herbal remedies used for gastrointestinal disorders in Kaghan Valley, NWFP, Pakistan. Pak. J. Weed Sci. Res 2008; 14: 169-200.

7. Iftikhar B, Perveen S, Malik A, Sultana N, Arayne S, Muhammad $P$. Structural determination of quercusides $A$ and $B$, new flavonoid glucosides from Quercus incana, by $1 D$ and $2 D$ NMR spectroscopy. Magn. Reson. Chem 2009; 47: 605-608.

8. CIRCOR. Guide for the ethical evaluation of experiments using laboratory animals. Paris, 2009. 13-14 p.

9. Khan H, Khan MA, Hussan I. Enzymes inhibition activities of the Gloriosa superba linn (colchicaceae) $J$ Enzyme Inhib and Med Chem 2007; 22: 677-684.
10. Bruce RD. An up-and-down procedure for acute toxicity testing. Fund Appl Toxicol 1985; 5: 151-157.

11. Trease GE, Evans WC. Pharmacognosy Alden Press, Oxford. 1996; $213 p$.

12. Gray AM, Spencer PSJ, Sewell RDE. The involvement of the opioidergic system in the antinociceptive mechanism of action of antidepressant compounds. Br. J. Pharmacol 1998; 124: 669-674.

13. Rauf A, Uddin G, Siddiqui BS, Muhammad N, Khan $H$ Antipyretic and antinociceptive activity of Diospyros lotus L. in animals. Asian Pacific Journal of Tropical Biomedicine 2014; 4: S382-S386.

14. Winter, CA, Risely, EA, Nuss, GW, Carrageenan induced edema in hind paw of the rat as an assay for antiinflammatory drugs. Proceedings of the Soc Exp Biol Med 1962; 111: 544-547.

15. Planichamy S, Nagarajan S. Anifungal activity of Cassia alata leaf extract. J Ethnopharmacol 1990; 29: 337.

16. Das, P. C. Das, A. and Mandal, S. Antimicrobial and anti-inflammatory activities of the seed kernel of Mangifera indica. Fitoterapia 1989; 60: 235-240.

17. Bentley GA, Newton SH, Starr J. Evidence for an action of morphine and the enkephalins on sensory nerve endings in the mouse peritoneum. Br J Pharmacol 1981; 73: 325-332.

18. Khan H, Saeed M, Gilani AH, Khan MA, Dar A, Khan I. The antinociceptive activity of Polygonatum verticillatum rhizomes in pain models. J Ethnopharmacol 2010; 127: 521-527.

19. Deradt R, Jougney S, Delevalcee F, Falhout M. Release of prostaglandin $E$ and $F$ in an algogenic reaction and its inhibition. Eur J Pharmacol 1980; 51: 17-24.

20. Ramabadran K, Bansinath M, Turndorf H, Puig MM. Tail immersion test for the evaluation of a nociceptive reaction in mice. Methodological consideration. J. Pharmacol. Meth 1989; 21: 21-31.

21. Wan J, Gong X, Jiang R, Zhang Z, Zhang L. Antipyretic and anti-inflammatory effects of asiaticoside inl Lipopolysaccharide-treated rat through up-regulation of heme oxygenase-1. Phytother Res 2013; 27: 11361142. 